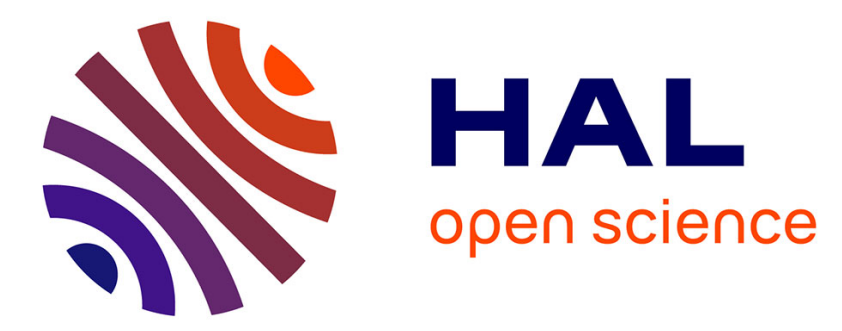

\title{
MR imaging of adult acute infectious encephalitis
}

Anne Bertrand, Delphine Leclercq, Laurent Martinez-Almoyna, Nadine

Girard, Jean Paul Stahl, Thomas Debroucker

\section{To cite this version:}

Anne Bertrand, Delphine Leclercq, Laurent Martinez-Almoyna, Nadine Girard, Jean Paul Stahl, et al.. MR imaging of adult acute infectious encephalitis. Médecine et Maladies Infectieuses, 2017, 10.1016/j.medmal.2017.01.002 . hal-01490868

\section{HAL Id: hal-01490868 \\ https://hal.science/hal-01490868}

Submitted on 5 Jul 2017

HAL is a multi-disciplinary open access archive for the deposit and dissemination of scientific research documents, whether they are published or not. The documents may come from teaching and research institutions in France or abroad, or from public or private research centers.
L'archive ouverte pluridisciplinaire HAL, est destinée au dépôt et à la diffusion de documents scientifiques de niveau recherche, publiés ou non, émanant des établissements d'enseignement et de recherche français ou étrangers, des laboratoires publics ou privés. 


\title{
MR imaging of adult acute infectious encephalitis
}

\section{IRM des encéphalites aiguës infectieuses de l'adulte}

\author{
Anne Bertrand ${ }^{1}$, Delphine Leclercq ${ }^{2}$, L Almoyna-Martinez ${ }^{3}$, N Girard $^{4}$, JP Stahl ${ }^{5}$, T De Broucker $^{6}$
}

1 - Service de Neuroradiologie Diagnostique et Fonctionnelle, Groupe Hospitalier Pitié-Salpêtrière 47-83 boulevard de l'hôpital, 75651 Paris cedex 13 ; Sorbonne Universités, UPMC Univ Paris 06, Inserm, CNRS, Institut du cerveau et la moelle (ICM) ; Inria Paris, Aramis project-team, 75013, Paris, France. anne.bertrand@aphp.fr

2 - Service de Neuroradiologie Diagnostique et Fonctionnelle, Groupe Hospitalier Pitié-Salpêtrière 47-83 boulevard de l'hôpital, 75651 Paris cedex 13 delphine.leclercq@aphp.fr

3- Service de neurochirurgie, CHU Nord, AP-HM, Marseille 13015 Laurent.MARTINEZ-ALMOYNA@ap-hm.fr

4 - Service de neuroradiologie, CHU La Timone, AP-HM, Marseille 13015.nadine.girard@ap-hm.fr

5 - Service d'Infectiologie, CHU Grenoble, 38043 Grenoble.JPStahl@chu-grenoble.fr

6 -Service de Neurologie, CH Saint Denis, BP 279, 93205. thomas.debroucker@ch-stdenis.fr

Mots clés : encéphalite, IRM, HSV, VZV, infection

Keywords: encephalitis, MRI, HSV, VZV, infection 


\section{Summary}

Background. - Imaging is a key tool for the diagnosis of acute encephalitis. Brain CT scan must be urgently performed to rule out a brain lesion with mass effect that would contraindicate lumbar puncture. Brain MRI is less accessible than $\mathrm{CT}$, but can provide crucial informations in patients with acute encephalitis.

Method. - We performed a literature review on PubMed on April 1, 2015, with the search terms "MRI" and "encephalitis".

Results. - We first describe the various brain MRI abnormalities associated with each pathogen of acute encephalitis (HSV, VSV, other viral agents targeting immunocompromized patients or travelers; tuberculosis, listeriosis, other less frequent bacterial agents). Then, we identify specific patterns of brain MRI abnomalies that can suggest a particular pathogen. Limbic encephalitis is highly suggestive of HSV; it also occurs less frequently in encephalitis due to HHSV6, Syphillis, Whipple disease and HIV primoinfection. Rhombencephalitis is suggestive of tuberculosis and listeriosis. Acute ischemic lesions can occur in patients with severe bacterial encephalitis, tuberculosis, VZV encephalitis, syphilis and fungal infections.

Conclusion. - Brain MRI plays a crucial role in the diagnosis of acute encephalitis: it detects brain signal changes that reinforce the clinical suspicion of encephalitis, especially when the causative agent is not identified by lumbar puncture; it can suggest a particular pathogen based on the pattern of brain abnormalities; it rules out important diffential diagnosis (vascular, tumoral or inflammatory causes). 


\section{Résumé}

Introduction. - L'imagerie cérébrale est essentielle au diagnostic d'encéphalite aiguë. Le scanner cérébral doit être réalisé en urgence afin d'exclure une lésion cérébrale avec effet de masse qui contre-indiquerait la ponction lombaire. L'IRM cérébrale est moins accessible que le scanner, mais peut apporter des informations importantes pour la prise en charge des patients ayant une encéphalite aiguë.

Méthode. - Revue de la littérature sur PubMed le $1^{\mathrm{er}}$ avril 2015, avec les mots clés " IRM » et « encéphalite ».

Résultats. Nous décrivons tout d'abord les différentes anomalies IRM associées à chaque agent pathogène de l'encéphalite aiguë (HSV, VSV, autres virus ciblant les patients immunodéprimés ou voyageurs ; tuberculose, listériose et autres agents bactériens moins fréquents). Ensuite, nous identifions des patterns spécifiques d'anomalies IRM qui peuvent orienter vers un pathogène en particulier. L'encéphalite limbique est très évocatrice de I'HSV ; elle survient aussi moins fréquemment dans les encéphalites dues au HHSV6, à la syphilis, à la maladie de Whipple et à la primo-infection par le VIH. Une rhombencéphalite doit fait rechercher la tuberculose et la listériose. Des lésions ischémiques aiguës peuvent survenir chez des patients atteints d'encéphalite bactérienne grave, de tuberculose, d'encéphalite à VZV, de syphilis et d'infections fongiques.

Conclusion. - L'IRM cérébrale joue un rôle crucial dans le diagnostic des encéphalites aiguë : elle permet de détecter des anomalies de signal cérébrales qui renforcent la suspicion clinique d'encéphalite, en particulier lorsque l'agent causal n'est pas identifié par la ponction lombaire; elle peut suggérer un pathogène particulier en fonction du pattern des anomalies cérébrales; elle permet d'éliminer des diagnostics différentiels importants (causes vasculaires, tumorales ou inflammatoires). 


\section{Introduction}

Acute infectious encephalitis can be a life-threatening condition, and may sometimes be cured if an early and appropriate treatment is initiated. Acute infectious encephalitis is caused by a large number of pathogens [(1-3)]. Diagnosis is suspected on the basis of acute neurological symptoms and infectious signs, but it can be challenging in cases of atypical presentations. Brain imaging is crucial for the diagnosis of acute encephalitis. A brain CT scan must urgently be performed to rule out a brain lesion with mass effect that would contraindicate lumbar puncture. After lumbar puncture is performed, brain MRI is the modality of choice for acute encephalitis [(4)]. Brain MRI allows for detecting abnormalities suggestive of the diagnosis, and sometimes even suggestive of the pathogen; it also estimates the extent of brain damage, that will condition the prognosis; finally, it rules out important differential diagnoses, such as cerebral venous thrombosis, stroke, posterior reversible encephalopathy syndrome, or brain tumor [(1)]. In the present work, we reviewed the various $M R$ findings in brain encephalitis using two successive and complementary approaches: we first reviewed the various MR abnormalities that can be associated with each pathogen, and we then reviewed the various pathogens that can be suspected for particular pattern of brain involvement on MRI.

\section{Material and methods}

We performed a PubMed search on April 1, 2015, using the search terms "MRI " and « encephalitis ». We retrieved 5,436 articles published between 1982 and 2015 . We first reviewed the most recent 1,500 articles (i.e., from mid-2010 to 2015) to compile a list of pathogens involved in acute encephalitis and for which brain MRI studies were available. We then reviewed the articles that included the name of each pathogen. We excluded from this review the articles on differential diagnoses (paraneoplastic encephalitis, autoimmune or inflammatory encephalitis), those limited to neonate or children cases, those in which the infectious agent had not been formally identified, and those without MR imaging data. We also excluded non-original works (i.e., editorial, opinions). We also did not take into consideration articles focusing on HIV-related opportunistic infections, which are beyond the scope of our review. The final choice of articles and the references included are based on our judgment of their relevance to this subject. 


\section{Results}

1. MRI findings in acute encephalitis: a pathogen-based approach

\section{a. Viral encephalitis}

\section{Herpes simplex virus (HSV) encephalitis}

HSV encephalitis (HSVE) is the most common cause of infectious encephalitis [(1)]; it is a severe condition with $10-20 \%$ case fatality and a high rate of sequelae $[(5,6)]$. Rapid diagnosis of HSVE is crucial, as delayed treatment is associated with poor outcome [(5)]. Delay in brain imaging has been reported as an independent factor for delayed treatment [(7)]. HSVE is predominantly caused by HSV type 1 in adults and by HSV type 2 in neonates. Recent studies have shown that brain MRI has a high sensitivity for the diagnosis of HSVE, showing brain abnormalities in 80 to $100 \%$ of cases $[(1,6,8-10)]$; however, a normal brain MRI does not rule out HSVE diagnosis. Patients suspected of having HSVE may initially have a negative PCR for HSV but suggestive lesions on brain MRI, thus reinforcing the diagnosis of HSVE [(6,9-11)]. HSVE typically affects the limbic system: most frequently the medial temporal lobes [(9)], but also the insular, cingulate and frontobasal cortex; lesions are unilateral in $64-68 \%$ of cases [(6)]. Brain MRI typically shows area of T2 and FLAIR hyperintensities involving both the cortex and the white matter; areas of contrast enhancement can also be present. Basal ganglia are usually spared, although a few cases of basal ganglia involvement have been reported in $\operatorname{HSVE}[(12,13)]$. The frequent seizures associated with HSVE may also lead to reversible hyperintense FLAIR signal in the thalamus of patients [(14)]. Isolated brainstem involvement is rare [(15)]. Diffusion-weighted imaging (DWI) seems to be the most sensitive sequence for detecting HSV encephalitis at the acute phase, typically showing hyperintense lesions with restricted apparent diffusion coefficient (ADC) [(16-21)]. In the subacute phase of treated HSVE (>10 days), the ADC decreases and DWI seems less sensitive than T2 and FLAIR imaging for lesion depiction $[(19,21,22)]$. Severe presentations of HSVE show cortical and subcortical hemorrhagic necrosis, characterized by hypointense $\mathrm{T} 2 *$ signal and $\mathrm{T} 1$ hyperintense laminar necrosis. Lobar hematoma is rare [(2326)]. Extensive lesions on MRI are associated with a poor prognosis [(6)]. 


\section{Varicella-zoster virus (VZV) encephalitis}

VZV encephalitis affects both immunocompetent and immunocompromised patients. Immunocompetent individuals primarily affected by VZV encephalitis are the children and the elderly [(27)]. VZV encephalitis occurs after zoster or varicella, although there is no evidence of cutaneous rash in about $30 \%$ of patients [(28)]. The typical presentation of VZV encephalitis is a vasculopathy causing ischemic infarction and arterial stenosis. It can be either unifocal or multifocal and can affect both large and small arteries (most frequently both) [(28)]. In cases with large artery involvement, brain MRI can show large ischemic lesions and arterial stenosis, with a frequent localization at the M1 segment of the middle cerebral artery, and at the termination of the carotid artery [(29)]. High-resolution MRI sequences dedicated to vessel wall imaging can show contrast enhancement within the arterial wall [(29-31)], which may or may not regress after treatment [(29)]. In cases with small artery involvement, brain MRI shows small ischemic lesions at the grey-white matter junction and in the deep territories, without evidence of arterial stenosis $[(28,32)]$. Less frequently, VZV vasculopathy can also present as subarachnoid and cerebral hemorrhage $[(33,34)]$, aneurysms $[(35,36)]$, and carotid artery dissection [(37)]. The exact sensitivity of brain MRI in VZV encephalitis is difficult to estimate as literature data is scarce, and because most studies report case patients who either did not have brain MRI systematically performed [(38)] or were selected on the basis of vasculopathy on MRI [(28)]. It should be emphasized that a negative angiogram does not rule out VZV vasculopathy, as arterial stenosis cannot be depicted when only small arteries are affected [(28)].

\section{Viral encephalitis of the immunocompromised patient}

HIV primary infection may present as acute encephalitis. Brain MRI is usually unremarkable $[(39,40)]$, although there are a few case reports of HIV primary infections presenting as acute limbic encephalitis $[(41,42)]$ or acute cerebral vasculitis with ischemia $[(43)]$.

HHV6 is the causative agent of exanthema subitum. It can cause encephalopathy either during primary infection in children or during reactivation in immunocompromised patients, most frequently after allogeneic hematopoietic stem cell (AHSC) transplantation. These 
reactivations are frequent; they occur in almost $40 \%$ of cases after AHSC transplantation, and cause acute encephalitis in only $6 \%$ of cases after AHSC transplantation [(44)]. Patients usually present with memory deficits, cognitive deficits, fever, and seizures [(45)]. Brain MRI shows hyperintense T2 and DWI lesions often limited to the mesial temporal lobes, that may reverse on follow-up imaging [(46)]. Enhancement and hemorrhagic necrosis is usually absent [(45)]. Early brain MRI may be normal [(45)].

CMV reactivation in immunocompromised patients manifests as acute ventriculitis. T2 hyperintensities and contrast enhancement are present along the wall of the ventricles [(47)], but may be difficult to depict; DWI may facilitate the detection of periventricular abnormalities, suggesting the diagnosis [(48)].

JC virus reactivation in immunocompromised patients causes progressive multifocal leukoencephalopathy (PML), a severe demyelinating disease of the brain. It mostly affects 1 ) AIDS patients 2) multiple sclerosis (MS) patients treated with natalizumab, a humanized monoclonal antibody against $\alpha 4$ integrin used in severe presentations of $\mathrm{MS}$, but it can also occur in other causes of immunosuppression (after organ transplantation, bone marrow transplantation, leukemia) [(49)]. Clinical symptoms are not those of acute encephalitis: they include progressive neurological deficits and cognitive dysfunction, in the absence of systemic inflammatory signs [(49)]. Brain MRI typically shows subcortical white matter lesions with no or minimal mass effect, high signal on $\mathrm{T} 2 \mathrm{WI}$, very low signal on $\mathrm{T} 1 \mathrm{WI}$, no or minimal peripheral contrast enhancement, and a suggestive peripheral hyperintense ring on DWI [(50)].A punctate pattern of T2 hyperintensities, and the presence of SWI hypointensities within the adjacent grey matter, are suggestive of the diagnosis $(51,52)$. MR spectroscopy in PML lesions shows increased choline and myo-inositol, decreased $\mathrm{N}$ acetylaspartate (NAA), and presence of lactates [(53)].

BK virus is a rare cause of encephalitis in immunocompromised patients. It can be suspected when neurological symptoms are associated with urological manifestations [(54)]. Brain MRI may show limbic encephalitis [(55)] or diffuse T2 and DWI hyperintensities in the white matter, associated with restricted diffusion [(54)]. 


\section{Viral encephalitis of the traveler}

These various pathogens do not require the administration of a specific treatment; thus, an MRI diagnosis is not as crucial as for other types of viral encephalitis.

\section{Eastern Europe}

Tick-borne encephalitis is caused by a flavivirus. On brain MRI, lesions predominate within the basal ganglia and the cerebellum [(56)]. Reversible splenial lesions on DWI have been reported [(57)].

\section{Tropical and subtropical areas}

Dengue is the second cause of mosquito-borne disease in humans, after malaria. When symptomatic, dengue fever is associated with neurological features in 1 to $20 \%$ of cases [(58)]. Patients presenting with dengue encephalitis may have a normal brain MRI, or nonspecific changes such as edema and meningeal enhancement with variable pattern (either supratentorial, infratentorial, limbic, within the basal ganglia or the splenium of corpus callosum) [(58-62)]. Hemorrhages or microhemorrhages may occur [(62,63)]. Areas of DWI hyperintensities with restricted ADC can be present [(60)].

Chikungunya virus infection usually manifests as acute febrile arthralgia in patients who recently travelled to an area of outbreak. Chikungunya infection can also cause acute encephalitis; brain MRI is usually normal [(64)], except for a case report of multiple small stroke-like lesions in the white matter [(65)].

\section{Asia}

Japanese encephalitis is a mosquito-borne disease caused by a flavivirus. The MRI most frequently shows bilateral areas of high $\mathrm{T} 2$ intensity within the basal ganglia, thalamus, substantia nigra, and midbrain, but abnormalities can also be observed within the hippocampus and cortex [(66)]. Meningeal enhancement may be present [(67)]. Hemorrhages, however, are rare [(68)]. Reversible splenial lesions on DWI have been reported [(69)].

Nipah virus is transmitted to human by mammals, especially pigs, and causes outbreaks in Malaisia, Bangladesh and India(70). Brain MRI show small, multiple, corticosubcortical FLAIR- 
hyperintense lesions, sometimes hyperintense on DWI, sometimes hemorrhagic with hypointensities on T2-weighted images and hyperintensities on T1-weighted images $(71,72)$.

\section{Australia}

Hendra virus is transmitted to human by horses. Brain MRI shows multiple T2 and DWI hyperintensities with restricted $A D C$, predominating in cortical and subcortical areas; meningeal enhancement may occur [].

Murray Valley virus causes a mosquito-borne disease. Brain MRI shows bilateral T2 hyperintensity of the basal ganglia and thalamus, that can extend to the temporal lobe [(73)], midbrain, and cerebellum in severe presentations [(74)]. Meningeal enhancement may be present $[(74)]$.

\section{America / Caribbean}

West Nile virus is a mosquito-borne disease caused by a flavivirus. Brain MRI may be normal $[(75,76)]$ or demonstrate increased $T 2$ signal intensity within the basal ganglia, the pons, the mesial temporal lobe, and the anterior horns or the spinal cord; leptomeningeal enhancement can also be present [(76-78)]. West Nile virus is endemic in the United States [(78)] and recent outbreaks have been reported in Europe [(79-81)].

Eastern equine encephalitis is a rare and severe mosquito-borne disease [(82)]. Brain MRI classically demonstrates symmetrical T2 hyperintensities which predominate in the basal ganglia and the thalamus $[(82,83)]$, and may be enhanced with contrast agent injection $[(82)]$.

\section{Other less frequent ubiquitous viral pathogens}

Influenza virus is a common pathogen that rarely causes encephalitis. Brain MRI may be normal or show non-specific changes within the cortex, white matter, basal ganglia, brain stem, and cerebellum. Patients present with acute necrotizing encephalopathy [(84-88)]. Reversible splenial lesions have been reported $[(87,89)]$. MRI findings do not appear to be strain-specific, as similar abnormalities have been observed during the recent H1N1 outbreak [(90-93)]. 
Hepatitis A virus may cause acute encephalitis. MRI findings occasionally show reversible splenial DWI hyperintensity with restricted diffusion in these patients $[(94,95)]$. Meningeal enhancement has also been reported [(96)].

Epstein-Barr virus (EBV) infection, or reactivation in immunocompromised patients, can cause acute encephalitis. Brain MRI can be normal [(97)], or demonstrate areas of T2 hyperintensities within the cortex and/or the basal ganglia and substantia nigra [(98-102)]. Areas of hyperintensities on DWI with restricted ADC may be present [(103)]. White matter reversible lesions [(104,105)] and hemorrhagic leukoencephalitis [(106)] have also been reported.

Subacute sclerosing panencephalitis is a rare and fatal complication occurring years after measles virus infection. Brain MRI usually shows multiple T2 hyperintensities in the white matter and grey matter of patients $[(107,108)]$, with increased ADC [(109)]. Lesions may look like pseudotumors $[(110,111)]$, or suggest an inflammatory demyelinating disease $[(110,112)]$. Limbic [(113)] or brainstem [(114)] involvement is also possible.

Rubella is a rare cause of encephalitis in adults. Reversible splenial lesions on DWI have been reported [(115)].

Mumps is a rare cause of encephalitis in adults. Reversible splenial lesions on DWI have been reported $[(116,117)]$. Claustrum hyperintense lesions [(118)] and deep necrotic lesions [(119)] have also been reported.

Rabies encephalitis is a fatal infectious disease, transmitted through bites by rabid animals. Rabies occurs in Africa and Asia, and has recently re-emerged in Southern Europe [(120)]. Brain MRI usually demonstrates symmetrical T2 hyperintensities within the grey matter nuclei of the basal ganglia, thalamus, midbrain, and pons [(121)]. 


\section{b. Bacterial encephalitis}

\section{Tuberculosis}

Tuberculosis (TB) is the $3^{\text {rd }}$ cause of acute infectious encephalitis $[(1,2)]$.

MRI findings evocative of cerebral TB comprise:

- Basal meningitis. Leptomeningitis can be depicted on MRI as spontaneously hyperintense leptomeningeal spaces on FLAIR sequence, enhancing after gadolinium injection on T1 and FLAIR sequences. TB leptomeningitis predominates in the basal cisterns and Sylvian fissures, but can later extend to the convexity [(122)]. Leptomeningeal enhancement can be associated with cranial nerve enhancement and citernal necrotic abcesses [(122)]. Pachymeningitis may also occur in TB, mimicking a meningioma $[(123,124)]$.

- Hydrocephalus. Hydrocephalus during TB is most commonly non-communicating, caused by obstruction to CSF flow in the basal cisterns by inflammatory exudates. Obstructive hydrocephalus may also occur as a result of the mass effect of a tuberculoma or ventriculitis [(125)].

- Vasculitis. TB vasculitis is a consequence of the inflammatory changes of the leptomeninges of basal cisterns, which surround the arteries of the circle of Willis. Narrowing or occlusion of intracranial arteries is most frequently proximal (basilar artery with its perforant branches, internal carotid atery, proximal parts of the anterior, middle and posterior cerebral arteries with their perforant branches), and affects more frequently the anterior circulation $[(126,127)]$. They can be depicted on conventional angio-MRI (magnetic resonance angiography imaging) or angio-CT (computed tomography angiography). Acute infarcts are observed in $25-60 \%$ of patients presenting with CNS tuberculosis [(127,128)]; they are most frequently multiple and located within the deep territories of perforant branches.

- TB cerebritis may present as area of high T2 signal in the brain parenchyma, often adjacent to the areas of leptomeningeal enhancement [(122)]. In later stages, tuberculomas or abscesses can form in the parenchyma. They initially appear as solid-enhancing lesions, and later as ring-enhancing lesions with central necrosis. They may be caused either by a spread of TB from the leptomeningeal spaces to the 
adjacent parenchyma via the perivascular spaces, or by a hematogenous spread in cases of miliary TB. High T1 signal and low T2 signal within the solid portions of tuberculomas are suggestive of TB, but non-specific (also observed in fungal infections, lymphoma, and tumors with a high CSF cell count). The presence of lipid peaks on spectroscopy in necrotic TB lesions is non-specific (also observed in metastasis, glioblastoma, pyogenic abscess).

However, a normal brain MRI does not rule out acute TB encephalitis. The authors of a recent prospective study of encephalitis observed that $55 \%(6 / 11)$ of patients presenting with acute TB encephalitis for whom brain MRI was available had normal MRI findings (no abnormality, or non-specific FLAIR hyperintensities in the parenchyma) [(129)]. This low sensitivity of brain MRI could probably be improved using appropriate sequences (contrastenhanced FLAIR sequence for detecting subtle meningeal enhancement, DWI sequence and 3D time of flight (3DTOF) for detecting acute ischemia and arterial stenosis).

\section{Listeria monocytogenes}

Listeria monocytogenes is a Gram-positive intracellular bacterium that penetrates the intestinal, blood-brain, and fetoplacental barriers. It has a specific affinity for the central nervous system, especially in cell-mediated immunodeficient individuals [(130)]. It may present as acute meningitis and/or encephalitis. About half of the patients presenting with acute Listeria encephalitis have an underlying comorbidity (diabetes, chronic renal failure, alcoholism, cirrhosis, pregnancy, chemotherapy, or corticoid therapy) or underlying immunosuppression (hematologic malignancy, transplantation, HIV infection) [(131)]. Brain MRI is abnormal in $64 \%$ of neurological Listeria cases (either meningitis or encephalitis) [(131)]. In one-third of cases, brain MRI demonstrates rhombencephalitis, i.e. increased T2 signal and mass effect [(131-133)]. Parenchymal microabscesses or true abscesses may occur; they are most frequently located within the brainstem [(133)], but they can also be observed within the hemispheres $[(134,135)]$. Non-specific sign of meningitis may also be observed (i.e., hyperintense leptomeningeal spaces on FLAIR sequence, enhancing after gadolinium injection on T1 and FLAIR sequences). Hydrocephalus occurs in $20 \%$ of cases $[(131)]$. 


\section{Other less common bacteria}

Borrelia burgdorferi is the causal agent of Lyme disease, a multisystem disorder predominantly affecting the skin, but it may also involve the central nervous system. Neurological Lyme disease manifests as painful lymphocytic meningoradiculitis; encephalitis remains a rare complication [(136)]. Brain MRI may show leptomeningeal and cranial nerve enhancement.

Treponema pallidum is the causal agent of syphilis. Neurosyphilis has been reported to cause limbic encephalitis, with T2 and FLAIR hyperintensities within the mesiotemporal lobes, sometimes extending to the insula [(137-139)], mimicking HSV encephalitis. Acute ischemic lesions have also been reported.

Tropheryma whipplei is the causal agent of Whipple's disease. Neurological manifestations of Whipple's disease are rare complications that appear most frequently in patients whose treatment did not include antibiotics able to cross the blood-brain barrier [(140)]. Brain MRI can demonstrate hyperintense T2 lesions within the medial temporal lobes, hypothalamus, and pons [(141-143)].

Bartonella henselae is the causal agent of cat scratch disease (CSD). CSD typically presents in children and young adults as febrile lymphadenitis 1 to 3 weeks after scratch, bite, or lick from a cat $[(144)]$. Acute encephalopathy occurs in up to $3 \%$ of all CSD cases $[(145,146)]$. Seizures are frequent and sometimes severe, and many reported brain MRI abnormalities (cortical and thalamic T2 hyperintensities, meningeal enhancement) could have been induced by repeated seizures $[(147,148)]$. Non-enhancing corticosubcortical nodular lesions [(149)] and pachymeningeal enhancing mass [(150)] have been reported, both with complete regression after antibiotic treatment.

Salmonella infections are frequently associated with non-infectious neurological complication, including encephalopathy. Acute cerebellitis may be observed on brain MRI $[(151,152)]$. Diffuse white matter hyperintensities have been reported, hyperintense on DWI and corresponding to restricted ADC [(153)]; they may reflect the consequences of the septic shock syndrome rather than specific pathogen-induced lesions. Reversible splenial lesions on DWI have also been reported $[(154,155)]$. 
Mycoplasma pneumoniae is a frequent cause of acute pneumonia, especially in children, and may cause encephalitis. Brain MRI is frequently abnormal, with preferential involvement of the brainstem, cerebellum, and basal ganglia [(156)].

\section{MRI findings in acute encephalitis: a pattern-based} approach

\section{a. Limbic encephalitis}

HSV1 encephalitis is a frequent cause of limbic encephalitis, and early treatment is crucial for its long-term prognosis. Thus, HSV1 should first be considered in any patients presenting with acute limbic encephalitis.

HHV6 encephalitis may also be suspected in case of acute limbic encephalitis in patients who underwent allogeneic hematopoietic stem cell transplantation. HHV6 encephalitis lesions are usually less severe than HSV1 encephalitis lesions; they are often limited to the mesial temporal lobes; contrast enhancement and necrotic and hemorrhagic changes are usually absent. Lesions may reverse on follow-up imaging, even in cases of decreased ADC on initial imaging $[(45,46)]$.

Neurosyphilis, Whipple's disease, and HIV primary infection are rare causes of limbic encephalitis that can benefit from a specific treatment.

Autoimmune/paraneoplastic limbic encephalitis and HSV1 encephalitis presentations may be very similar. They can manifest as acute symptoms including fever, seizures, neurological deficits, and memory impairment. Lumbar puncture shows lymphocytic pleocytosis and elevated protein levels, and MRI demonstrates T2 hyperintensities within the limbic system. MRI abnormalities can be asymmetrical or unilateral, and contrast enhancement may be 
present [(157-159)]. Thus, HSV1 encephalitis should first be considered in this setting. Subtle differences have been reported between the two groups, yet none of them can rule out HSVE [(157)]:

- psychiatric symptoms are more frequent in patients with autoimmune/paraneoplastic encephalitis patients than in patients wirth HSVE;

- acute onset, fever, and aphasia are more frequent in patients with HSVE than in patients with autoimmune/paraneoplastic encephalitis;

- a normal brain MRI is rare in patients with HSVE, but frequent (40\%) in patients with autoimmune/paraneoplastic encephalitis;

- on MRI, diffuse insular and temporal lobe involvement, necrotic and hemorragic changes, sparing of basal ganglia are more frequent in patients with HSVE than in patients with autoimmune/paraneoplastic encephalitis;

- on MRI, symmetrical lesions are more frequent in autoimmune/paraneoplastic encephalitis than in HSVE .

However, none of these findings can rule out HSVE.

Recently, it has been reported that HSVE patients may present a neurological relapse 1 to 3 months after the initial encephalitis, due to HSVE-induced autoimmune encephalitis associated with anti-N-methyl- d-aspartate receptor (NMDA-R)(160,161). This rare complication is important to diagnose, as it may be confused with a true HSVE relapse, but it requires specific immunotherapeutic treatments.

Glioma or gliomatosis cerebri may present as acute neurological symptoms and may mimic limbic encephalitis $[(157,162,163)]$. HSV1 encephalitis should always be considered on initial MRI. Lumbar puncture showing isolated mild pleocytosis, together with clinical and radiological follow-up, can correct the diagnosis. 


\section{b. Rhombencephalitis}

The two most frequent infectious agents causing rhombencephalitis are Listeria monocytogenes and Mycobacterium tuberculosis [(164)]. They should first be suspected in acute rhombencephalitis because of the need to initiate a specific treatment. The presence of leptomeningeal enhancement and/or brainstem abscesses reinforces the suspicion of Listeria or TB. The association with focal arterial narrowing and strokes specifically favors a suspicion of tuberculosis. Rhombencephalitis have also been reported in encephalitis due to Mycoplasma pneumoniae, HSV1 and HHV6 $(15,156)$.

Behçet's disease is a frequent cause of acute rhombencephalitis and the main differential diagnosis of infectious rhombencephalitis [(164)].

Neuromyelitis optica spectrum disorder should be included in the differential diagnosis of acute rhombencephalitis as isolated brainstem involvement is possible [(165)]. The classic "area postrema syndrome" manifests as uncontrollable nausea and vomiting, corresponding on brain MRI to hyperintense lesions in the dorsal brainstem [(165)].

Posterior reversible encephalopathy syndrome sometimes present as isolated brainstem/cerebellar involvement, and should be included in the differential diagnoses of rhombencephalitis [(166)].

Neurosarcoidosis, other granulomatosis, and histiocytosis can involve the brainstem and cause $\mathrm{T} 2$ hyperintensities, mass effect, and contrast enhancement [(167)].

\section{c. Acute encephalitis with ischemic lesions}

The presence of acute ischemic lesions on brain MRI in patients with a suspicion of acute infectious encephalitis should first raise the possibility of an acute endocarditis.

Bacterial encephalitismay be associated with acute ischemic lesions [(168)]. Tuberculosis is a common cause of arteritis and may lead to small ischemic lesions [(122)]. VZV encephalitis 
can be associated with acute ischemic stroke, especially in the territory of the middle cerebral artery [(28)]. In immunocompromised patient, acute encephalitis with acute ischemic lesions observed should raise the suspicion of fungal infection, especially cerebral aspergillosis and candidiasis; or neurosyphilis [(103,169)].

\section{d. Splenial reversible DWI hyperintensity (MERS)}

Mild Encephalopathy with Reversible Splenial Lesion (MERS) is a clinical and radiological syndrome associating a mild encephalopathy (behavioral changes, altered consciousness, seizures) and an oval-shaped, well-limited signal abnormality within the splenium of corpus callosum, hyperintense on T2WI and DWI, corresponding to restricted ADC. Both clinical and radiological abnormalities spontaneously resolve within days or weeks. The mechanism of MERS remains unknown.

MERS has been linked to numerous infectious agents, either bacterial (Legionella pneumophila [(170)], Enterococcus faecalis [(171)], Escherichia coli, Staphylococcus aureus, Salmonella enteritidis $[(154,155)])$, or viral (CMV, influenza, mumps, rubella, hepatitis A, adenovirus, flavivirus $[(57,69,115,172)])$. However, MERS can also be caused by many noninfectious conditions such as seizures, antiepileptic drugs, hypoglycemia, high-altitude brain injury, and acute axonal injury.

\section{Conclusion}

Brain MRI plays a crucial role in the diagnosis of acute encephalitis. It can demonstrate brain signal abnormalities and contrast enhancement, and reinforce a clinical suspicion of encephalitis, especially when identification of the causal agent by lumbar puncture is lacking. A good knowledge of the MRI patterns of brain involvement can also help physicians in suspecting a particular pathogen. However, MRI patterns must be interpreted in light of the clinical context (frailty, immunosuppression, recent travel), and should always integrate the differential diagnoses, mainly related to vascular, tumoral and inflammatory causes. 


\section{References}

1. Granerod J, Ambrose HE, Davies NW, Clewley JP, Walsh AL, Morgan D, et al. Causes of encephalitis and differences in their clinical presentations in England: a multicentre, population-based prospective study. Lancet Infect Dis. déc 2010;10(12):835-44.

2. Mailles A, Stahl J. Infectious Encephalitis in France in 2007: A National Prospective Study. Clin Infect Dis. 15 déc 2009;49(12):1838-47.

3. Quist-Paulsen E, Kran A-MB, Dunlop O, Wilson J, Ormaasen V. Infectious encephalitis: a description of a Norwegian cohort. Scand J Infect Dis. mars 2013;45(3):179-85.

4. Steiner I, Budka H, Chaudhuri A, Koskiniemi M, Sainio K, Salonen O, et al. Viral meningoencephalitis: a review of diagnostic methods and guidelines for management: Viral meningoencephalitis. Eur J Neurol. 3 mars 2010;17(8):999-e57.

5. Raschilas F, Wolff M, Delatour F, Chaffaut C, De Broucker T, Chevret S, et al. Outcome of and prognostic factors for herpes simplex encephalitis in adult patients: results of a multicenter study. Clin Infect Dis Off Publ Infect Dis Soc Am. 1 août 2002;35(3):254-60.

6. Sili U, Kaya A, Mert A, HSV Encephalitis Study Group. Herpes simplex virus encephalitis: clinical manifestations, diagnosis and outcome in 106 adult patients. J Clin Virol Off Publ Pan Am Soc Clin Virol. juin 2014;60(2):112-8.

7. Poissy J, Wolff M, Dewilde A, Rozenberg F, Raschilas F, Blas M, et al. Factors associated with delay to acyclovir administration in 184 patients with herpes simplex virus encephalitis. Clin Microbiol Infect Off Publ Eur Soc Clin Microbiol Infect Dis. juin 2009;15(6):560-4.

8. Dagsdóttir HM, Sigurðardóttir B, Gottfreðsson M, Kristjánsson M, Löve A, Baldvinsdóttir GE, et al. Herpes simplex encephalitis in Iceland 1987-2011. SpringerPlus. 2014;3:524.

9. Sheybani F, Arabikhan HR, Naderi HR. Herpes Simplex Encephalitis (HSE) and its outcome in the Patients who were Admitted to a Tertiary Care Hospital in Mashhad, Iran, over a 10-year Period. J Clin Diagn Res JCDR. août 2013;7(8):1626-8.

10. Riera-Mestre A, Gubieras L, Martínez-Yelamos S, Cabellos C, Fernández-Viladrich P. Adult herpes simplex encephalitis: fifteen years' experience. Enfermedades Infecc Microbiol Clínica. mars 2009;27(3):143-7.

11. Akyldz BN, Gümüş H, Kumandaş S, Coşkun A, Karakukuçu M, Yklmaz A. Diffusionweighted magnetic resonance is better than polymerase chain reaction for early diagnosis of herpes simplex encephalitis: a case report. Pediatr Emerg Care. juin 2008;24(6):377-9.

12. Mondal G, Kumar R, Ghosh JK, Basu K, Chatterjee S. Basal ganglia involvement in a 
child with herpes simplex encephalitis. Indian J Pediatr. juill 2009;76(7):749-50.

13. Navin P, Delanty N, Brennan P, Looby S. Herpes simplex virus encephalitis involving the right thalamus. BMJ Case Rep. 2013;2013.

14. Huang Y-C, Weng H-H, Tsai Y, Huang Y-C, Hsiao M-C, Wu C-Y, et al. Periictal magnetic resonance imaging in status epilepticus. Epilepsy Res. sept 2009;86(1):72-81.

15. Arita JH, Lin J, Peruchi MM, Rodrigues MM, Vilanova LCP. Herpes simplex type 1 encephalitis restricted to the brainstem in a pediatric patient. Case Rep Med. 2010;2010:606584.

16. Schleede L, Bueter W, Baumgartner-Sigl S, Opladen T, Weigt-Usinger K, Stephan S, et al. Pediatric herpes simplex virus encephalitis: a retrospective multicenter experience. J Child Neurol. mars 2013;28(3):321-31.

17. Herweh C, Jayachandra MR, Hartmann M, Gass A, Sellner J, Heiland S, et al. Quantitative diffusion tensor imaging in herpes simplex virus encephalitis. J Neurovirol. oct 2007;13(5):426-32.

18. Obeid M, Franklin J, Shrestha S, Johnson L, Quattromani F, Hurst D. Diffusionweighted imaging findings on MRI as the sole radiographic findings in a child with proven herpes simplex encephalitis. Pediatr Radiol. nov 2007;37(11):1159-62.

19. Duckworth JL, Hawley JS, Riedy G, Landau ME. Magnetic resonance restricted diffusion resolution correlates with clinical improvement and response to treatment in herpes simplex encephalitis. Neurocrit Care. 2005;3(3):251-3.

20. Heiner L, Demaerel P. Diffusion-weighted MR imaging findings in a patient with herpes simplex encephalitis. Eur J Radiol. 2003;45(3):195-198.

21. K $\geqslant$ ker W, N $\geqslant$ gele T, Schmidt F, Heckl S, Herrlinger U. Diffusion-weighted MRI in herpes simplex encephalitis: a report of three cases. Neuroradiology. 1 févr 2004;46(2):122-5.

22. Sawlani V. Diffusion-weighted imaging and apparent diffusion coefficient evaluation of herpes simplex encephalitis and Japanese encephalitis. J Neurol Sci. déc 2009;287(1-2):221-6.

23. Rodríguez-Sainz A, Escalza-Cortina I, Guio-Carrión L, Matute-Nieves A, GómezBeldarrain M, Carbayo-Lozano G, et al. Intracerebral hematoma complicating herpes simplex encephalitis. Clin Neurol Neurosurg. oct 2013;115(10):2041-5.

24. Saxena A, Khiangte B, Tiewsoh I, Jajoo UN. Herpes zoster encephalitis presenting as multiple cerebral hemorrhages - a rare presentation: a case report. J Med Case Reports. 2013;7:155.

25. Lo WB, Wilcock DJ, Carey M, Albanese E. Neurological picture. Herpes encephalitis complicated by cerebral haemorrhage. J Neurol Neurosurg Psychiatry. déc 2013;84(12):1404-6. 
26. Takeuchi S, Takasato Y. Herpes simplex virus encephalitis complicated by intracerebral hematoma. Neurol India. août 2011;59(4):594-6.

27. Gilden D, Cohrs RJ, Mahalingam R, Nagel MA. Varicella zoster virus vasculopathies: diverse clinical manifestations, laboratory features, pathogenesis, and treatment. Lancet Neurol. août 2009;8(8):731-40.

28. Nagel MA, Cohrs RJ, Mahalingam R, Wellish MC, Forghani B, Schiller A, et al. The varicella zoster virus vasculopathies: Clinical, CSF, imaging, and virologic features. Neurology. 11 mars 2008;70(11):853-60.

29. Cheng-Ching E, Jones S, Hui FK, Man S, Gilden D, Bhimraj A, et al. High-resolution MRI vessel wall imaging in varicella zoster virus vasculopathy. J Neurol Sci. avr 2015;351(1-2):168-73.

30. Katchanov J, Siebert E, Klingebiel R, Endres M. Infectious Vasculopathy of Intracranial Large- and Medium-Sized Vessels in Neurological Intensive Care Unit: A Clinico-Radiological Study. Neurocrit Care. 10 févr 2010;12(3):369-74.

31. Swartz RH, Bhuta SS, Farb RI, Agid R, Willinsky RA, terBrugge KG, et al. Intracranial arterial wall imaging using high-resolution 3-tesla contrast-enhanced MRI. Neurology. 17 févr 2009;72(7):627-34.

32. Chiang F, Panyaping T, Tedesqui G, Sossa D, Costa Leite C, Castillo M. Varicella Zoster CNS Vascular Complications: A Report of Four Cases and Literature Review. Neuroradiol J. 2014;27:0.

33. Matsuo K, Uozumi Y, Miyamoto H, Tatsumi S, Kohmura E. Varicella-Zoster Vasculitis Presenting with Cerebellar Hemorrhage. J Stroke Cerebrovasc Dis Off J Natl Stroke Assoc. 31 mars 2015;

34. González-Suárez I, Fuentes-Gimeno B, Ruiz-Ares G, Martínez-Sánchez P, DiezTejedor E. Varicella-zoster virus vasculopathy. A review description of a new case with multifocal brain hemorrhage. J Neurol Sci. 15 mars 2014;338(1-2):34-8.

35. Bhayani N, Ranade P, Clark NM, McGuinn M. Varicella-zoster virus and cerebral aneurysm: case report and review of the literature. Clin Infect Dis Off Publ Infect Dis Soc Am. 1 juill 2008;47(1):e1-3.

36. Liberman AL, Nagel MA, Hurley MC, Caprio FZ, Bernstein RA, Gilden D. Rapid development of 9 cerebral aneurysms in varicella-zoster virus vasculopathy. Neurology. 10 juin 2014;82(23):2139-41.

37. Constantinescu CS. Association of varicella-zoster virus with cervical artery dissection in 2 cases. Arch Neurol. mars 2000;57(3):427.

38. De Broucker T, Mailles A, Chabrier S, Morand P, Stahl J-P, on behalf of the steering committee and investigators group. Acute varicella zoster encephalitis without evidence of primary vasculopathy in a case-series of 20 patients. Clin Microbiol Infect. août 2012;18(8):808-19. 
39. Ragin AB, Wu Y, Gao Y, Keating S, Du H, Sammet C, et al. Brain alterations within the first 100 days of HIV infection. Ann Clin Transl Neurol. janv 2015;2(1):12-21.

40. Nzwalo H, Anon RP, Aguas MJ. Acute encephalitis as initial presentation of primary HIV infection. Case Rep. 3 juill 2012;2012(jul02 1):bcr0320125970-bcr0320125970.

41. Scriven J, Davies S, Banerjee AK, Jenkins N, Watson J. Limbic encephalitis secondary to HIV seroconversion. Int J STD AIDS. avr 2011;22(4):236-7.

42. Ferrada MA, Xie Y, Nuermberger E. Primary HIV infection presenting as limbic encephalitis and rhabdomyolysis. Int J STD AIDS. 20 nov 2014;

43. Helleberg M, Kirk O. Encephalitis in primary HIV infection: challenges in diagnosis and treatment. Int J STD AIDS. juin 2013;24(6):489-93.

44. Yamamoto W, Ogusa E, Matsumoto K, Maruta A, Ishigatsubo Y, Kanamori H. Human herpesvirus- 6 encephalopathy after hematopoietic stem cell transplantation and class I human leukocyte antigen. Clin Transplant. mai 2014;28(5):540-5.

45. Bhanushali MJ, Kranick SM, Freeman AF, Cuellar-Rodriguez JM, Battiwalla M, GeaBanacloche JC, et al. Human herpes 6 virus encephalitis complicating allogeneic hematopoietic stem cell transplantation. Neurology. 16 avr 2013;80(16):1494-500.

46. Noguchi T, Yoshiura T, Hiwatashi A, Togao O, Yamashita K, Nagao E, et al. CT and MRI Findings of Human Herpesvirus 6-Associated Encephalopathy: Comparison With Findings of Herpes Simplex Virus Encephalitis. Am J Roentgenol. mars 2010;194(3):754-60.

47. «Owl's eyes » of CMV ventriculitis. Neurology. 27 juin 2000;54(12):2217-2217.

48. Seok JH, Ahn K, Park HJ. Diffusion MRI findings of cytomegalovirus-associated ventriculitis: a case report. Br J Radiol. sept 2011;84(1005):e179-181.

49. Berger JR. The clinical features of PML. Cleve Clin J Med. 1 nov 2011;78(Suppl_2):S8-12.

50. Sahraian MA, Radue E-W, Eshaghi A, Besliu S, Minagar A. Progressive multifocal leukoencephalopathy: a review of the neuroimaging features and differential diagnosis. Eur J Neurol Off J Eur Fed Neurol Soc. août 2012;19(8):1060-9.

51. Hodel J, Outteryck O, Verclytte S, Deramecourt V, Lacour A, Pruvo J-P, et al. Brain Magnetic Susceptibility Changes in Patients with Natalizumab-Associated Progressive Multifocal Leukoencephalopathy. Am J Neuroradiol. 1 déc 2015;36(12):2296-302.

52. Hodel J, Darchis C, Outteryck O, Verclytte S, Deramecourt V, Lacour A, et al. Punctate pattern A promising imaging marker for the diagnosis of natalizumabassociated PML. Neurology. 2016;86(16):1516-1523.

53. Sahraian MA, Radue E-W, Eshaghi A, Besliu S, Minagar A. Progressive multifocal leukoencephalopathy: a review of the neuroimaging features and differential diagnosis: Progressive multifocal leukoencephalopathy. Eur J Neurol. août 2012;19(8):1060-9. 
54. Friedman DP, Flanders AE. MR Imaging of BK virus encephalitis. Am J Neuroradiol. 2006;27(5):1016-1018.

55. Chittick P, Williamson JC, Ohl CA. BK virus encephalitis: case report, review of the literature, and description of a novel treatment modality. Ann Pharmacother. sept 2013;47(9):1229-33.

56. Horger M, Beck R, Fenchel M, Ernemann U, Nägele T, Brodoefel H, et al. Imaging findings in tick-borne encephalitis with differential diagnostic considerations. AJR Am J Roentgenol. août 2012;199(2):420-7.

57. Vollmann H, Hagemann G, Mentzel H-J, Witte OW, Redecker C. Isolated reversible splenial lesion in tick-borne encephalitis: a case report and literature review. Clin Neurol Neurosurg. juin 2011;113(5):430-3.

58. Carod-Artal FJ, Wichmann O, Farrar J, Gascón J. Neurological complications of dengue virus infection. Lancet Neurol. 2013;12(9):906-919.

59. Misra UK, Kalita J, Syam UK, Dhole TN. Neurological manifestations of dengue virus infection. J Neurol Sci. 15 mai 2006;244(1-2):117-22.

60. Mathew T, Badachi S, Sarma GRK, Nadig R. « Dot sign » in dengue encephalitis. Ann Indian Acad Neurol. mars 2015;18(1):77-9.

61. Bhoi SK, Naik S, Kumar S, Phadke RV, Kalita J, Misra UK. Cranial imaging findings in dengue virus infection. J Neurol Sci. 15 juill 2014;342(1-2):36-41.

62. Hegde V, Aziz Z, Kumar S, Bhat M, Prasad C, Gupta AK, et al. Dengue encephalitis with predominant cerebellar involvement: Report of eight cases with MR and CT imaging features. Eur Radiol. mars 2015;25(3):719-25.

63. Borawake K, Prayag P, Wagh A, Dole S. Dengue encephalitis. Indian J Crit Care Med Peer-Rev Off Publ Indian Soc Crit Care Med. juill 2011;15(3):190-3.

64. Tournebize P, Charlin C, Lagrange M. [Neurological manifestations in Chikungunya: about 23 cases collected in Reunion Island]. Rev Neurol (Paris). janv 2009; 165(1):48-51.

65. Ganesan K, Diwan A, Shankar SK, Desai SB, Sainani GS, Katrak SM. Chikungunya Encephalomyeloradiculitis: Report of 2 Cases with Neuroimaging and 1 Case with Autopsy Findings. Am J Neuroradiol. 26 juin 2008;29(9):1636-7.

66. Handique SK, Das RR, Barman K, Medhi N, Saharia B, Saikia P, et al. Temporal lobe involvement in Japanese encephalitis: problems in differential diagnosis. Am J Neuroradiol. 2006;27(5):1027-1031.

67. Verma R. MRI features of Japanese encephalitis. BMJ Case Rep. 2012;2012.

68. Mokkappan S, Basheer A, Iqbal N, Chidambaram S. Bilateral thalamic bleed and cerebral venous sinus thrombosis in Japanese encephalitis. BMJ Case Rep. 2015;2015. 
69. Man BL, Fu YP. The first case of mild encephalopathy with a reversible splenial lesion due to Japanese encephalitis virus infection. BMJ Case Rep. 2013;2013.

70. Arif SM, Basher A, Quddus MR, Faiz MA. Re-emergence Nipah - a review. Mymensingh Med J MMJ. oct 2012;21(4):772-9.

71. Lim CCT, Lee KE, Lee WL, Tambyah PA, Lee CC, Sitoh YY, et al. Nipah Virus Encephalitis: Serial MR Study of an Emerging Disease. Radiology. 1 janv 2002;222(1):219-26.

72. Sarji SA, Abdullah BJ, Goh KJ, Tan CT, Wong KT. MR imaging features of Nipah encephalitis. AJR Am J Roentgenol. août 2000;175(2):437-42.

73. Knox J, Cowan RU, Doyle JS, Ligtermoet MK, Archer JS, Burrow JNC, et al. Murray Valley encephalitis: a review of clinical features, diagnosis and treatment. Med J Aust. 19 mars 2012;196(5):322-6.

74. Speers DJ, Flexman J, Blyth CC, Rooban N, Raby E, Ramaseshan G, et al. Clinical and radiological predictors of outcome for Murray Valley encephalitis. Am J Trop Med Hyg. mars 2013;88(3):481-9.

75. Cooper CJ, Said S. West nile virus encephalitis induced opsoclonus-myoclonus syndrome. Neurol Int. 22 avr 2014;6(2):5359.

76. Racsa L, Gander R, Chung W, Southern P, Le J, Beal S, et al. Clinical features of West Nile virus epidemic in Dallas, Texas, 2012. Diagn Microbiol Infect Dis. févr 2014;78(2):132-6.

77. Guth JC, Futterer SA, Hijaz TA, Liotta EM, Rosenberg NF, Naidech AM, et al. Pearls \& oy-sters: bilateral thalamic involvement in West Nile virus encephalitis. Neurology. 8 juill 2014;83(2):e16-17.

78. Petersen LR, Brault AC, Nasci RS. West Nile virus: review of the literature. JAMA. 17 juill 2013;310(3):308-15.

79. Popovic N, Milosevic B, Urosevic A, Poluga J, Popovic N, Stevanovic G, et al. Clinical characteristics and functional outcome of patients with West Nile neuroinvasive disease in Serbia. J Neurol. juin 2014;261(6):1104-11.

80. Ocal M, Onder H, Arsava EM, Alp S, Ozkul A, Ergünay K. [A case of central nervous system infection due to west nile virus lineage-1 in ankara province, Turkey]. Mikrobiyoloji Bül. janv 2013;47(1):164-72.

81. Capuzzo M, Cadorin D, Perna P, Vitali S, Libanore M, Cavazzini L, et al. West Nile Virus encephalitis in intensive care: a small mosquito, a tremendous danger. Minerva Anestesiol. déc 2011;77(12):1224-7.

82. Deresiewicz RL, Thaler SJ, Hsu L, Zamani AA. Clinical and Neuroradiographic Manifestations of Eastern Equine Encephalitis. N Engl J Med. juin 1997;336(26):1867-74. 
83. Babi M-A, Raleigh T, Shapiro RE, McSherry J, Applebee A. MRI and encephalography in fatal eastern equine encephalitis. Neurology. 14 oct 2014;83(16):1483.

84. Thabet FI, Khalil S, Naz F, Dyme IZ. Cerebellar mutism and reversible cytotoxic edema in influenza B-associated encephalopathy. Pediatr Neurol. déc 2013;49(6):489-92.

85. Sangle SA, Vadgaonkar G, Kadam DB, Chadha M. Influenza A (H3N2) associated acute necrotising encephalopathy. J Assoc Physicians India. janv 2011;59:52-4.

86. Studahl M. Influenza virus and CNS manifestations. $\mathrm{J}$ Clin Virol. déc 2003;28(3):225-32.

87. Matsubara K, Kodera M, Nigami H, Yura K, Fukaya T. Reversible splenial lesion in influenza virus encephalopathy. Pediatr Neurol. déc 2007;37(6):431-4.

88. Dicky O, Cheuret E, Berthomieu L. [Severe neurological forms of influenza in children: report on three cases of severe encephalitis in France]. Arch Pédiatrie Organe Off Sociéte Fr Pédiatrie. mai 2014;21(5):514-7.

89. Abenhaim Halpern L, Agyeman P, Steinlin M, El-Koussy M, Grunt S. Mild encephalopathy with splenial lesion and parainfluenza virus infection. Pediatr Neurol. mars 2013;48(3):252-4.

90. Umemura S, Yamasaki M, Takahashi Y, Matsumoto K, Miyamura M. [An adult case of pandemic (H1N1) 2009 influenza associated encephalopathy]. Rinshō Shinkeigaku Clin Neurol. juin 2011;51(6):422-5.

91. Surana P, Tang S, McDougall M, Tong CYW, Menson E, Lim M. Neurological complications of pandemic influenza A H1N1 2009 infection: European case series and review. Eur J Pediatr. août 2011;170(8):1007-15.

92. Kim KJ, Park ES, Chang HJ, Suh M, Rha D-W. Novel Influenza A (H1N1)-Associated Acute Necrotizing Encephalopathy: A Case Report. Ann Rehabil Med. avr 2013;37(2):286-90.

93. Ito S, Shima S, Ueda A, Kawamura N, Asakura K, Mutoh T. Transient splenial lesion of the corpus callosum in H1N1 influenza virus-associated encephalitis/encephalopathy. Intern Med Tokyo Jpn. 2011;50(8):915-8.

94. Kwon D-Y, Kim JH, Koh S-B, Park MH, Park K-W. Reversible splenial lesion in adult hepatitis A virus associated encephalopathy. Acta Neurol Belg. juin 2010;110(2):214.

95. Ko SY, Kim BK, Kim DW, Kim JH, Choe WH, Seo HY, et al. Reversible splenial lesion on the corpus callosum in nonfulminant hepatitis A presenting as encephalopathy. Clin Mol Hepatol. déc 2014;20(4):398-401.

96. Mathew T, Aroor S, Nadig R, Sarma G. Focal meningoencephalitis of hepatitis A: a clinico-radiologic picture. Pediatr Neurol. sept 2012;47(3):222-3. 
97. Barón J, Herrero-Velázquez S, Ruiz-Piñero M, Pedraza MI, Rojo-Rello S, GuerreroPeral ÁL. [Encephalitis due to the Epstein-Barr virus: a description of a clinical case and review of the literature]. Rev Neurol. 16 nov 2013;57(10):451-4.

98. Engelmann I, Nasser H, Belmiloudi S, Le Guern R, Dewilde A, Vallée L, et al. Clinically severe Epstein-Barr virus encephalitis with mild cerebrospinal fluid abnormalities in an immunocompetent adolescent: a case report. Diagn Microbiol Infect Dis. juin 2013;76(2):232-4.

99. Alarcón F, Dueñas G, Lees A. Encephalitis lethargica due to Epstein-Barr virus infection. Mov Disord Off J Mov Disord Soc. sept 2011;26(11):2132-4.

100. Hashemian S, Ashrafzadeh F, Akhondian J, Beiraghi Toosi M. Epstein-barr virus encephalitis: a case report. Iran J Child Neurol. 2015;9(1):107-10.

101. Guan J, Lu Z, Zhou Q. Reversible parkinsonism due to involvement of substantia nigra in Epstein-Barr virus encephalitis. Mov Disord Off $\mathbf{J}$ Mov Disord Soc. janv 2012;27(1):156-7.

102. Salel M, Tanchoux F, Viguier A, Cognard C, Larrue V, Bonneville F. Reversible bilateral basal ganglia lesions related to Epstein-Barr virus encephalitis. J Neuroradiol J Neuroradiol. déc 2013;40(5):370-2.

103. Ozbek O, Koç O, Paksoy Y, Aydin K, Nayman A. Epstein-Barr virus encephalitis: findings of MRI, MRS, diffusion and perfusion. Turk J Pediatr. déc 2011;53(6):680-3.

104. Di Carlo P, Trizzino M, Titone L, Capra G, Colletti P, Mazzola G, et al. Unusual MRI findings in an immunocompetent patient with EBV encephalitis: a case report. BMC Med Imaging. 2011;11:6.

105. Jang YY, Lee KH. Transient asymptomatic white matter lesions following Epstein-Barr virus encephalitis. Korean J Pediatr. sept 2011;54(9):389-93.

106. Befort P, Gaillard N, Roubille C, Quellec AL. Hemorrhagic leukoencephalitis linked to Epstein-Barr virus in an adult patient. Clin Neurol Neurosurg. nov 2010;112(9):829-31.

107. Jagtap SA, Nair MD, Kambale HJ. Subacute sclerosing panencephalitis: A clinical appraisal. Ann Indian Acad Neurol. 2013;16(4):631-3.

108. Steiner I, Livneh V, Hoffmann C, Nass D, Mor O, Chapman J. Steroid-responsive, progressive, focal measles virus brain infection. Ann Neurol. juin 2014;75(6):967-70.

109. Abuhandan M, Cece H, Calik M, Karakas E, Dogan F, Karakas O. An evaluation of subacute sclerosing panencephalitis patients with diffusion-weighted magnetic resonance imaging. Clin Neuroradiol. mars 2013;23(1):25-30.

110. Panda AK, Mehta VJ, Maheshwari S, Kar SK. Subacute sclerosing panencephalitis presenting as acute disseminated encephalomyelitis and pseudotumour cerebri. BMJ Case Rep. 2013;2013. 
111. Azad ZR, Patil AKB, Sivadasan A, Mani S, Alexander M. Rapidly progressive SSPE masquerading as cerebral gliomatosis. Neurol India. déc 2012;60(6):656-7.

112. Raut TP, Singh MK, Garg RK, Naphade PU. Subacute sclerosing panencephalitis presenting as neuromyelitis optica. BMJ Case Rep. 2012;2012.

113. Lebon S, Maeder P, Maeder-Ingvar M, Poloni C, Mayor-Dubois C, Roulet-Perez E, et al. An initial MRI picture of limbic encephalitis in subacute sclerosing panencephalitis. Eur J Paediatr Neurol EJPN Off J Eur Paediatr Neurol Soc. nov 2011;15(6):544-6.

114. Sharma P, Singh D, Singh MK, Garg RK, Kohli N. Brainstem involvement in subacute sclerosing panencephalitis. Neurol India. avr 2011;59(2):273-5.

115. Jinnai A, Kikuchi T, Ishikawa M, Nishimura Y, Shibata K, Sakura H. [A case of rubella encephalitis presenting as clinically mild encephalitis/encephalopathy with a reversible splenial lesion]. Rinshō Shinkeigaku Clin Neurol. 2014;54(8):668-70.

116. Melenotte C, Craighero F, Girard N, Brouqui P, Botelho-Nevers E. Measles encephalitis the return: mild encephalitis with reversible splenial lesion. Int J Infect Dis IJID Off Publ Int Soc Infect Dis. janv 2013;17(1):e72-73.

117. Takanashi J-I, Shiihara T, Hasegawa T, Takayanagi M, Hara M, Okumura A, et al. Clinically mild encephalitis with a reversible splenial lesion (MERS) after mumps vaccination. J Neurol Sci. 15 févr 2015;349(1-2):226-8.

118. Ishii K, Tsuji H, Tamaoka A. Mumps virus encephalitis with symmetric claustrum lesions. AJNR Am J Neuroradiol. août 2011;32(7):E139.

119. Suga K, Goji A, Shono M, Matsuura S, Inoue M, Toda E, et al. Mumps encephalitis with akinesia and mutism. Pediatr Int Off J Jpn Pediatr Soc. 25 mars 2015;

120. Stahl J-P, Mailles A. What is new about epidemiology of acute infectious encephalitis?: Curr Opin Neurol. juin 2014;27(3):337-41.

121. Jain H, Deshpande A, Favaz AM, Rajagopal KV. MRI in rabies encephalitis. BMJ Case Rep. 2013;2013.

122. Patkar D, Narang J, Yanamandala R, Lawande M, Shah GV. Central Nervous System Tuberculosis. Neuroimaging Clin N Am. nov 2012;22(4):677-705.

123. Adachi K, Yoshida K, Tomita H, Niimi M, Kawase T. Tuberculoma mimicking falx meningioma--case report. Neurol Med Chir (Tokyo). sept 2004;44(9):489-92.

124. Yanardag H, Uygun S, Yumuk V, Caner M, Canbaz B. Cerebral tuberculosis mimicking intracranial tumour. Singapore Med J. déc 2005;46(12):731-3.

125. Singh P, Paliwal VK, Neyaz Z, Srivastava AK, Verma R, Mohan S. Clinical and magnetic resonance imaging characteristics of tubercular ventriculitis: an underrecognized complication of tubercular meningitis. J Neurol Sci. 15 juill 2014;342(1-2):137-40. 
126. Singh B, Garg RK, Singh MK, Verma R, Malhotra HS, Jain A, et al. Computed tomography angiography in patients with tuberculous meningitis. J Infect. juin 2012;64(6):565-72.

127. Kalita J, Prasad S, Maurya PK, Kumar S, Misra UK. MR angiography in tuberculous meningitis. Acta Radiol. 1 avr 2012;53(3):324-9.

128. Wasay M, Farooq S, Khowaja ZA, Bawa ZA, Ali SM, Awan S, et al. Cerebral infarction and tuberculoma in central nervous system tuberculosis: frequency and prognostic implications. J Neurol Neurosurg Psychiatry. nov 2014;85(11):1260-4.

129. Honnorat E, De Broucker T, Mailles A, Stahl JP. Encephalitis due to Mycobacterium tuberculosis in France. Médecine Mal Infect. juin 2013;43(6):230-8.

130. Disson O, Lecuit M. Targeting of the central nervous system by Listeria monocytogenes. Virulence. 1 mars 2012;3(2):213-21.

131. Arslan F, Meynet E, Sunbul M, Sipahi OR, Kurtaran B, Kaya S, et al. The clinical features, diagnosis, treatment, and prognosis of neuroinvasive listeriosis: a multinational study. Eur J Clin Microbiol Infect Dis. juin 2015;34(6):1213-21.

132. Czupryna P, Zajkowska A, Garkowski A, Pancewicz S, Guziejko K, Moniuszko A, et al. Listerial rhombencephalitis in an immunocompetent woman. Case Rep Neurol Med. 2014;2014:674321.

133. Soulié D, Meyer P, Raynaud M, Berge J, Dousset V. [MRI and Listeria monocytogenes rhombencephalitis]. J Radiol. juill 1996;77(7):489-96.

134. Adeva-Bartolomé MT, de Castro-García FJ, Castellanos-Pinedo F, Zurdo-Hernández JM. [Brain abscesses due to Listeria monocytogenes]. Rev Neurol. 16 févr 2005;40(4):219-21.

135. DeJesus-Alvelo I, Merenda A. A Case Report of Listeria monocytogenes Abscesses Presenting as Cortically Predominant Ring-Enhancing Lesions. Case Rep Neurol. 30 avr 2015;7(1):105-9.

136. Koedel U, Fingerle V, Pfister H-W. Lyme neuroborreliosis-epidemiology, diagnosis and management. Nat Rev Neurol [Internet]. 28 juill 2015 [cité 29 juill 2015]; Disponible sur: http://www.nature.com/doifinder/10.1038/nrneurol.2015.121

137. Vedes E, Geraldo AF, Rodrigues R, Reimão S, Ribeiro A, Antunes F. Neurosyphilis versus Herpes Encephalitis in a Patient with Confusion, Memory Loss, and T2Weighted Mesiotemporal Hyperintensity. Case Rep Infect Dis. 2012;2012:154863.

138. Saunderson RB, Chan RC. Mesiotemporal changes on magnetic resonance imaging in neurosyphilis. Intern Med J. sept 2012;42(9):1057-63.

139. Xiang $\mathrm{T}$, Li G, Xiao L, Chen S, Zeng H, Yan B, et al. Neuroimaging of six neurosyphilis cases mimicking viral encephalitis. $J$ Neurol Sci. 15 nov 2013;334(1-2):164-6. 
140. Gerard A, Sarrot-Reynauld F, Liozon E, Cathebras P, Besson G, Robin C, et al. Neurologic presentation of Whipple disease: report of 12 cases and review of the literature. Medicine (Baltimore). nov 2002;81(6):443-57.

141. Kremer S, Besson G, Bonaz B, Pasquier B, Le Bas J-F, Grand S. Diffuse lesions in the CNS revealed by MR imaging in a case of Whipple disease. Am J Neuroradiol. 2001;22(3):493-495.

142. Helou J, Saliba G, Kolev I, Pierrot-Deseilligny C. Neuro-Whipple confirmed five years after a presumptive diagnosis of a primitive CNS vasculitis. J Neurol. juin 2008;255(6):925-6.

143. Blanc F, Ben Abdelghani K, Schramm F, Jaulhac B, Chatelus E, Sordet C, et al. Whipple limbic encephalitis. Arch Neurol. nov 2011;68(11):1471-3.

144. Jackson LA, Perkins BA, Wenger JD. Cat scratch disease in the United States: an analysis of three national databases. Am J Public Health. déc 1993;83(12):1707-11.

145. Carithers HA. Cat-scratch disease. An overview based on a study of 1,200 patients. Am J Dis Child 1960. nov 1985;139(11):1124-33.

146. Murakami K, Tsukahara M, Tsuneoka H, lino H, Ishida C, Tsujino K, et al. Cat scratch disease: analysis of 130 seropositive cases. J Infect Chemother Off J Jpn Soc Chemother. déc 2002;8(4):349-52.

147. Hahn JS, Sum JM, Lee KP. Unusual MRI findings after status epilepticus due to catscratch disease. Pediatr Neurol. mai 1994;10(3):255-8.

148. Rohr A, Saettele MR, Patel SA, Lawrence CA, Lowe LH. Spectrum of radiological manifestations of paediatric cat-scratch disease. Pediatr Radiol. nov 2012;42(11):1380-4.

149. Puligheddu M, Giagheddu A, Genugu F, Giagheddu M, Marrosu F. Epilepsia partialis continua in cat scratch disease. Seizure. avr 2004;13(3):191-5.

150. Roebuck DJ. Cat-scratch disease with an extraaxial mass. Am J Neuroradiol. 1998;19(7):1294-1295.

151. Teaching NeuroImages: Acute cerebellitis caused by Salmonella typhimurium [Internet]. [cité 3 août 2015]. Disponible sur: http://www.neurology.org/content/80/11/e118.full.pdf+html

152. Ali G, Rashid S, Kamli MA, Shah PA, Allaqaband GQ. Spectrum of neuropsychiatric complications in 791 cases of typhoid fever. Trop Med Int Health. avril 1997;2(4):314-8.

153. Ahmed M, Sureka J, Mathew V, Jakkani RK, Abhilash KPP. Magnetic resonance imaging findings in a fatal case of Salmonella typhi-associated encephalopathy: a case report and literature review. Neurol India. avr 2011;59(2):270-2.

154. Kobuchi N, Tsukahara H, Kawamura Y, Ishimori Y, Ohshima Y, Hiraoka M, et al. 
Reversible diffusion-weighted MR findings of Salmonella enteritidis-associated encephalopathy. Eur Neurol. 2003;49(3):182-4.

155. Ka A, Britton P, Troedson C, Webster R, Procopis P, Ging J, et al. Mild encephalopathy with reversible splenial lesion: an important differential of encephalitis. Eur J Paediatr Neurol EJPN Off J Eur Paediatr Neurol Soc. mai 2015;19(3):377-82.

156. Daxboeck F, Blacky A, Seidl R, Krause R, Assadian O. Diagnosis, Treatment, and Prognosis of Mycoplasma pneumoniae Childhood Encephalitis: Systematic Review of 58 Cases. J Child Neurol. 1 nov 2004;19(11):865-71.

157. Oyanguren B, Sánchez V, González FJ, de Felipe A, Esteban L, López-Sendón JL, et al. Limbic encephalitis: a clinical-radiological comparison between herpetic and autoimmune etiologies. Eur $\mathbf{J}$ Neurol Off $\mathbf{J}$ Eur Fed Neurol Soc. déc 2013;20(12):1566-70.

158. Kotsenas AL, Watson RE, Pittock SJ, Britton JW, Hoye SL, Quek AML, et al. MRI Findings in Autoimmune Voltage-Gated Potassium Channel Complex Encephalitis with Seizures: One Potential Etiology for Mesial Temporal Sclerosis. Am J Neuroradiol. 1 janv 2014;35(1):84-9.

159. Asaoka K, Shoji H, Nishizaka S, Ayabe M, Abe T, Ohori N, et al. Non-herpetic acute limbic encephalitis: cerebrospinal fluid cytokines and magnetic resonance imaging findings. Intern Med. 2004;43(1):42-48.

160. Schein F, Gagneux-Brunon A, Antoine J-C, Lavernhe S, Pillet S, Paul S, et al. Anti-Nmethyl-d-aspartate receptor encephalitis after Herpes simplex virus-associated encephalitis: an emerging disease with diagnosis and therapeutic challenges. Infection. 8 nov $2016 ; 1-5$.

161. Leypoldt F, Titulaer MJ, Aguilar E, Walther J, Bönstrup M, Havemeister S, et al. Herpes simplex virus-1 encephalitis can trigger anti-NMDA receptor encephalitis: case report. Neurology. 29 oct 2013;81(18):1637-9.

162. Nagata R, Ikeda K, Nakamura Y, Ishikawa Y, Miura K, Sato R, et al. A case of gliomatosis cerebri mimicking limbic encephalitis: malignant transformation to glioblastoma. Intern Med Tokyo Jpn. 2010;49(13):1307-10.

163. Sun P, Piao H, Guo X, Wang Z, Sui R, Zhang Y, et al. Gliomatosis cerebri mimicking acute viral encephalitis and with malignant transformation of partial lesions: A case report. Exp Ther Med. sept 2014;8(3):925-8.

164. Moragas M, Martínez-Yélamos S, Majós C, Fernández-Viladrich P, Rubio F, Arbizu T. Rhombencephalitis: A Series of 97 Patients. Medicine (Baltimore). juill 2011;90(4):256-61.

165. Kim HJ, Paul F, Lana-Peixoto MA, Tenembaum S, Asgari N, Palace J, et al. MRI characteristics of neuromyelitis optica spectrum disorder: An international update. Neurology. 17 mars 2015;84(11):1165-73. 
166. Central-variant posterior reversible encephalopathy syndrome: brainstem or basal ganglia involvement lacking cortical or subcortical cerebral edema. - PubMed [Internet]. [cité 12 août 2015]. Disponible sur: about:reader?url=http\%3A\%2F\%2Fwww.ncbi.nlm.nih.gov\%2Fpubmed\%2F23971457

167. Leclercq D, Trunet S, Bertrand A, Galanaud D, Lehéricy S, Dormont D, et al. Cerebral tumor or pseudotumor? Diagn Interv Imaging. oct 2014;95(10):906-16.

168. Jorens PG, Parizel PM, Demey HE, Smets K, Jadoul K, Verbeek MM, et al. Meningoencephalitis caused by Streptococcus pneumoniae: a diagnostic and therapeutic challenge. Diagnosis with diffusion-weighted MRI leading to treatment with corticosteroids. Neuroradiology. oct 2005;47(10):758-64.

169. Starkey J, Moritani T, Kirby P. MRI of CNS Fungal Infections: Review of Aspergillosis to Histoplasmosis and Everything in Between. Clin Neuroradiol. sept 2014;24(3):217-30.

170. Hibino M, Hibi M, Akazawa K, Hikino K, Oe M. [A case of Legionnaires' pneumonia accompanied by clinically mild encephalitis/encephalopathy with a reversible splenial lesion (MERS) with transient altered mental status and cerebellar symptoms, which responded to treatment by antibiotics and corticosteroid]. Nihon Kokyūki Gakkai Zasshi J Jpn Respir Soc. sept 2011;49(9):651-7.

171. Marked elevation of interleukin-6 in mild encephalopathy with a reversible splenial lesion (MERS) associated with acute focal bacterial nephritis c... - PubMed - NCBI [Internet]. [cité 30 juill 2015]. Disponible sur: http://www.ncbi.nlm.nih.gov.gate2.inist.fr/pubmed/23978488

172. Gallucci M, Limbucci N, Paonessa A, Caranci F. Reversible focal splenial lesions. Neuroradiology. juill 2007;49(7):541-4. 
Figure 1. HSV encephalitis.

Figure 1. Encéphalite herpétique.

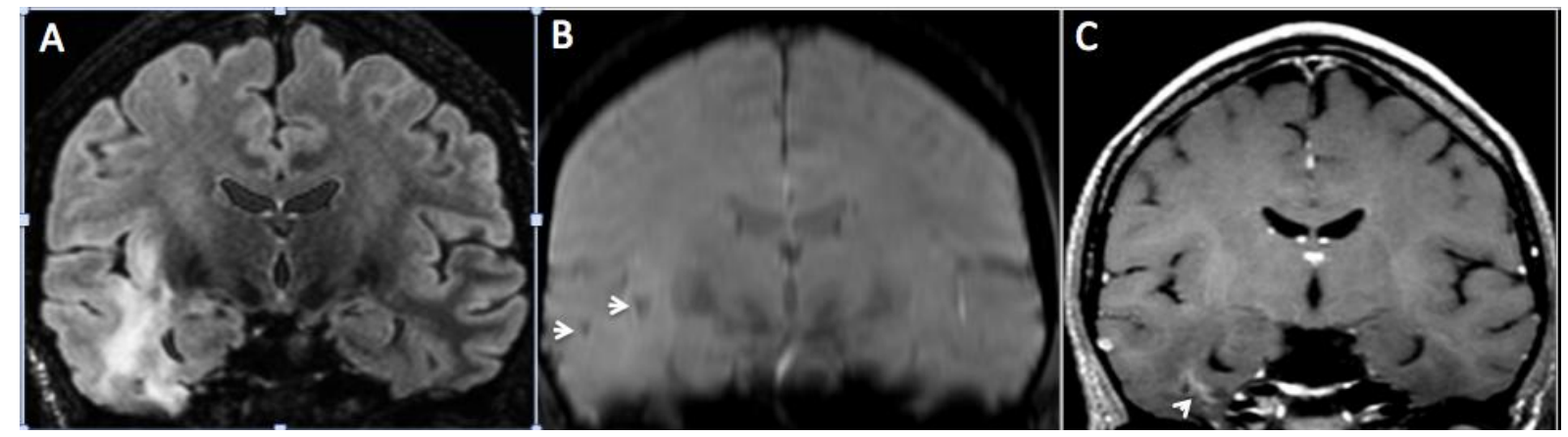

A: coronal FLAIR-weighted image demonstrates hyperintensities affecting the cortex and the white matter of right temporal and insular lobes.

B: T2* coronal image demonstrates small areas of parenchymal hemorrhage.

C: post-contrast coronal T1-weighted sequences shows areas of contrast enhancement within the right temporal lobe.

A : Coupe coronale en pondération FLAIR montrant des hyperintensités au niveau du cortex et de la substance blanche du lobe temporal droit et de l'insula.

B : Coupe coronale en pondération $\mathrm{T}^{*}$ montrant de petites zones d'hémorragies parenchymateuses.

C : Coupe coronale en pondération T1 après injection de produit de contraste, montrant des zones de rehaussement au niveau du lobe temporal droit. 
Figure 2. VZV encephalitis.

Figure 2. Encéphalite à VZV.

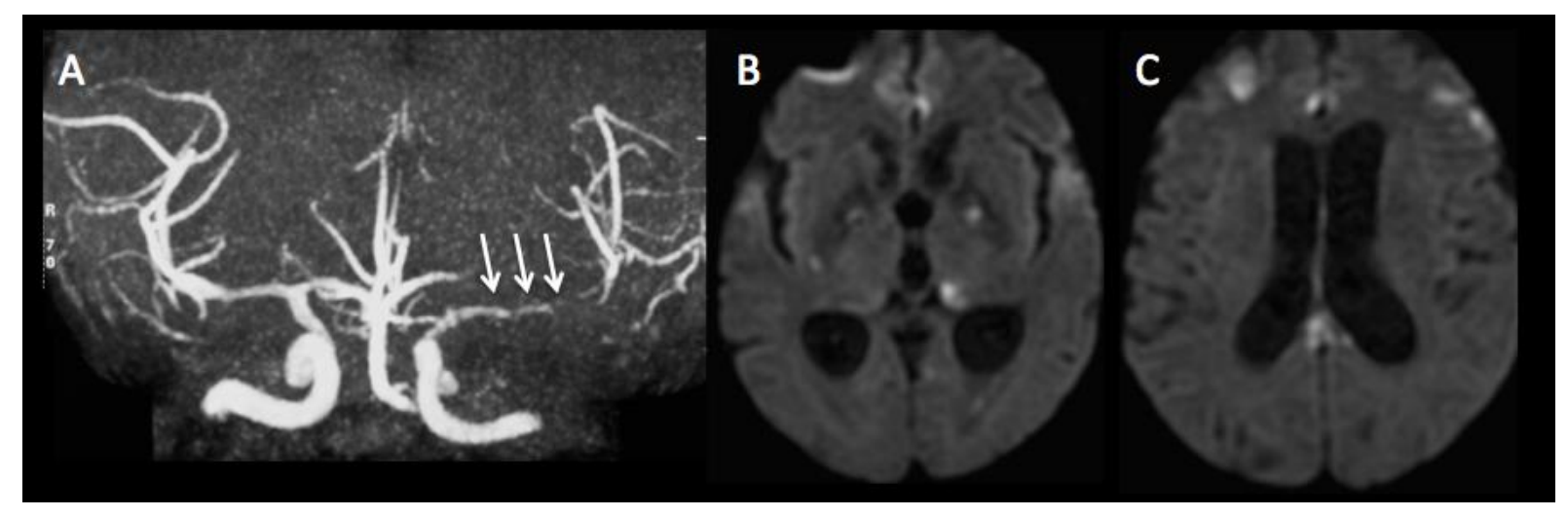

A: severe stenosis along the $M 1$ segment of the left middle cerebral artery.

B: multiple, bilateral, small ischemic lesions in another case of severe VZV encephalitis affecting small arteries.

A : sténose serrée le long du segment M1 de l'artère cérébrale moyenne gauche.

B : multiples petites lésions ischémiques bilatérales chez un autre patient atteint d'encéphalite grave à VZV touchant les petites artères. 
Figure 3. Neuromeningeal tuberculosis.

Figure 3. Tuberculose neuro-méningée.

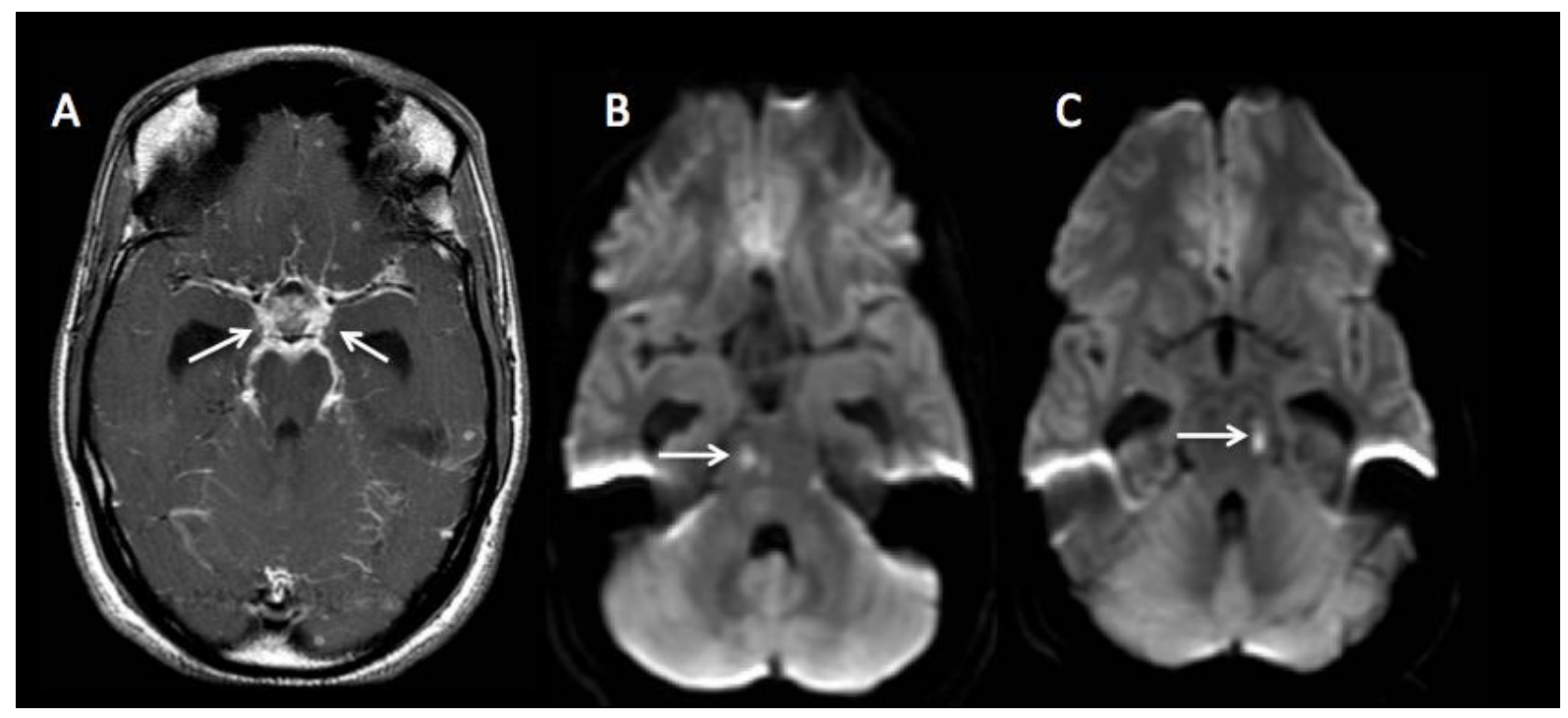

A: post-contrast axial T1-weighted image shows marked leptomeningeal enhancement in the basal cisterna, surrounding the arteries of the circle of Willis (arrows).

B\&C: DWI shows small, punctate ischemic lesions within the brain stem, in the territories of the perforating arteries (arrows).

A : coupe axiale pondérée T1 après injection de produit de contraste montrant un important rehaussement leptoméningé marqué des citernes de la base, autour des artères du polygone de Willis (flèches).

B \& C : I'imagere de diffusion montre de petites lésions ischémiques punctiformes du tronc cérébral, dans le territoire des artères perforantes (flèches). 
Figure 4. Neuromeningeal listeriosis.

Figure 4. Listériose neuro-méningée.

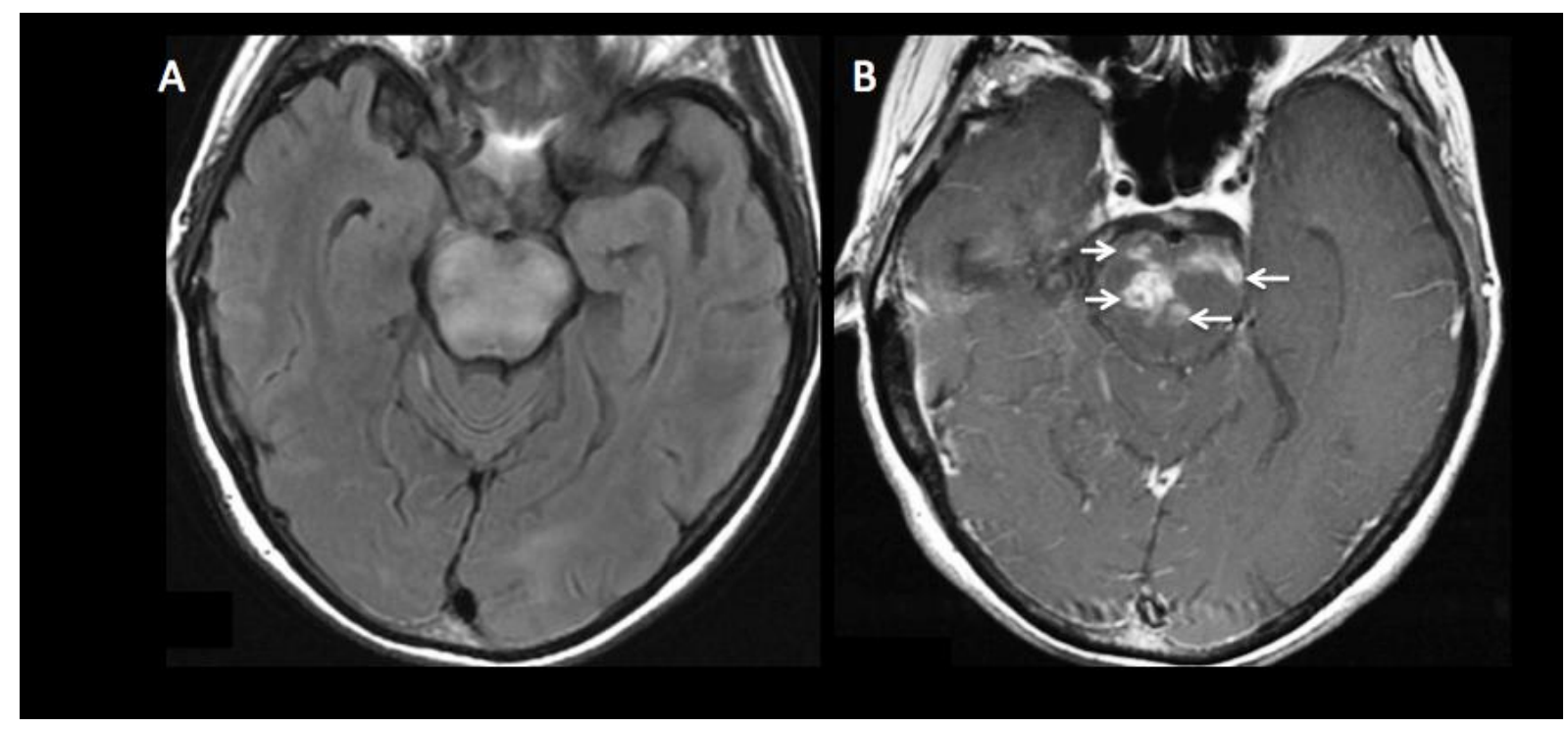

A: axial FLAIR-weighted image shows diffuse edema of the pons, reflecting acute rhombencephalitis.

B: post-contrast axial T1-weighted image shows multiple small abscesses within the pons, with peripheral ring-enhancement (arrows).

A : coupe axiale pondérée FLAIR montrant un œdème diffus du pont, témoignant d'une rhombencéphalite aiguë.

$B$ : coupe axiale pondérée $T 1$ après injection de produit de contraste montrant de multiples petits abcès du pont, avec un rehaussement annulaire (flèches). 